\title{
Limites entre a Bioética Católica e a Bioética Laica
}

\section{Limits lines between Catholic Bioethics and Laic Bioethics}

\author{
Cícero de Andrade Urban \\ Centro Universitário Positivo (Unicenp), Curitiba, Paraná, Brasil. \\ urban@onda.com.br
}

Resumo: Este artigo aborda as razões da dicotomia existente entre a Bioética Católica, baseada no personalismo ontologicamente fundado, e a Bioética Laica Secular. As duas correntes apresentam visões diversas sobre questões como: pesquisas com células-tronco, eutanásia e aborto. Atrás desta dicotomia histórica pode existir uma linha de convergência por meio do respeito à alteridade como princípio.

Palavras-chave: Bioética. Bioética Católica. Bioética Laica Secular. Alteridade.

\begin{abstract}
The present paper discusses the reasons of dichotomy between Bioethics of Catholic inspiration, Personalization Ontologically founded, and Secular Laic Bioethics. Both lines of thought present discordant visions about important questions like: stem-cell research, euthanasia and abortion. Behind this historic dichotomy a trend of convergence may be traced whenever respect for the principle of alterity is concerned.
\end{abstract}

Key-words: Bioethics. Catholic Bioethics. Secular Laic Bioethics. Altherity.

O Século XX procurou conceber a ciência como autônoma, isolada das instituições religiosas, da metafísica e também da filosofia, com temor de que estas pudessem contaminá-la com idéias supersticiosas que viessem em prejuízo da razão positiva. Entretanto, como afirmou Lain Entralgo, "...a ciência pode sempre mais daquilo que deve..." (1), e muitos acontecimentos fizeram com que a opinião pública e o ambiente acadêmico começassem a se preocupar com o desenvolvimento desordenado e sem controle do discurso científico. O distanciamento das humanidades tornou a ciência incompleta em seu objetivo fundamental de servir ao homem.

A bioética surgiu neste ambiente histórico conturbado e se desenvolveu mais precisamente devido a dois fatores fundamentais que 
foram marcantes: a preocupação com a proteção dos sujeitos vulneráveis nas pesquisas científicas e os pacientes na clínica; e o controle da biotecnologia e suas relações com a sobrevivência do homem. A experiência moral, por outro lado, sempre existiu nos seres humanos individuais e na coletividade. É o fenômeno que historicamente antecede o discurso bioético e é, também, como a bioética, objeto da razão positiva. Entretanto, ao mesmo tempo, é subordinada a aspectos considerados com menor dependência da razão, tais como as emoções, os valores, as crenças e as tradições, o que a torna ainda mais complexa em suas interpretações.

O verdadeiro desafio para a bioética contemporânea está no respeito à autonomia individual aliado à objetividade da ciência, inserindo-os em um sistema de valores que possam ser condivisíveis. Neste sentido, a bioética possui um vínculo irrenunciável com a ética filosófica. Constitui uma das maiores encarnações do espírito filosófico em toda a história, a ponto de caracterizar o ethos (originário do grego e escrito aqui com eta para significar morada) atual em que vivemos, assim como foram o Iluminismo e o Renascimento. Em poucas décadas a bioética tornou-se parte integrante do ambiente acadêmico e das discussões de alguns dos temas mais conflitantes na atualidade, vencendo uma série de críticas iniciais que lhe foram feitas. Para aqueles que estão envolvidos com ela, tanto no ambiente acadêmico quanto à beira do leito, encontrar no seio da sociedade pluralista e secular os elementos filosóficos para fundamentá-la na linguagem da razão e inserir tais elementos no discurso bioético é algo muitas vezes oneroso e difícil (2).

A contribuição dos teólogos, sobretudo os protestantes e católicos, assim como dos filósofos com inspiração cristã, foram marcantes para o desenvolvimento da ética profissional nos Estados Unidos da América (EUA) e, posteriormente, da bioética. De fato, algumas das figuras mais proeminentes da bioética mundial são teólogos e filósofos moralistas. Mesmo no meio brasileiro, grandes contribuições surgiram de pessoas com inspiração religiosa. Talvez porque a experiência moral, sobretudo aquela inserida dentro da tradição tomista, baseada na lei natural, não seja imposta de fora, mas uma exigência interna e pessoal, vivenciada como uma maneira de sintonizar a natureza humana imperfeita com a vontade de Deus. Assim, com esta fonte de inspira- 


\section{Revista Brasileira de Bioética}

ção, o bem seria a tendência natural para os seres humanos. Isto permitiu maior clareza de conceitual para estes indivíduos, em sua busca para estabelecer as fundamentações do discurso bioético.

Teilhard de Chardin, cuja vida foi devotada à reconciliação entre a ciência e a religião, serviu como ponto de referência para Potter, que dedicou a ele todo um capítulo do seu livro que deu origem à bioética (3). Mas a ética não precisa da fundamentação divina, mesmo considerando que existe proximidade entre a ética e a religião dentro da chamada experiência moral, em relação à exigência do dever e do absoluto, e da sua importância inegável para o surgimento da bioética. Para Jorge José Ferrer e Juan Carlos Alvarez reduzir a teologia e a religião à ética é empobrecê-las e reduzir a ética à teologia e à religião constituiria um grave problema para a sociedade pluralista e secular em que vivemos. Na tradição cristã, o núcleo da experiência religiosa encontra-se em Deus, no amor absoluto e não na observância de determinadas normas morais $(1 ; 2 ; 3 ; 4 ; 5)$.

Um elemento fundamental para a bioética e para a ética filosófica é o reconhecimento da alteridade, materializado pelo respeito ao próximo. Nesse sentido, aproxima-se novamente do discurso religioso, podendo prescindir deste sem que exista prejuízo prático. Um indivíduo em uma ilha deserta não tem necessidade da ética ou da bioética. Estaria isolado com as suas decisões, apenas buscando preservar sua existência, sem preocupar-se com os demais ou com a continuidade da espécie $(2 ; 3 ; 4 ; 5)$. Assim, como, então, se pode conceber a existência de uma bioética de inspiração católica e outra laica?

\section{O que é a Bioética Católica e qual a sua importância?}

Non videtur esse lex, quae justa non fuerit (uma lei injusta não é uma lei)

Santo Agostinho

Existe uma longa tradição na Igreja Católica de reflexão sobre temas que hoje são abordados pela bioética. Essa reflexão estende-se desde os escritos da patrística sobre o suicídio e sobre as leis, até os documentos recentes do Magistério da Igreja sobre eutanásia e reprodução assistida. A Bioética Católica está fundamentada na fé e 
na razão. Para a visão católica existe o paradigma da sacralidade da vida, que está articulado em três princípios fundamentais: a criação por Deus, a indisponibilidade e a inviolabilidade da vida humana (2; $4 ; 5)$. Apesar disso, a vida não é considerada um valor absoluto, pois o mais importante seria o que estaria esperando o fiel no post-mortem. Mesmo assim, dentro da lei natural da tradição tomista, a vida, sendo um dom, não poderia ser objeto de especulações utilitaristas.

Para Angelo Bompiani, sem renegar os fundamentos deontológicos, a linha teológica de matriz católica considera na sua totalidade a complexidade do agir humano: nas intenções do agente, nos valores em jogo, nas conseqüências que derivam das decisões e no ambiente sócio-cultural em que está inserido o sujeito. Apesar de admitir exceções em casos particulares, para o catequismo da Igreja Católica existem atos que, por si mesmos, independente das circunstâncias em que se encontrem e das intenções do sujeito, serão sempre ilícitos, tais como o homicídio e o adultério. Nesta visão, não é lícito realizar um mal, mesmo que com ele se possa atingir um bem $(2 ; 4 ; 5 ; 6 ; 7)$.

O conhecimento da bioética de inspiração católica é importante, pois pacientes e familiares que professam essa religião esperam que seus valores sejam respeitados, independente do credo do profissional de saúde responsável pelo seu cuidado. Além disso tal conhecimento, oferece uma visão diversa daquela existente na antropologia póscartesiana, que fundamenta a bioética laica secular, a qual insiste na primazia do agir sobre o ser, negando a existência de uma natureza humana pré-constituída. A bioética de inspiração católica é representada na Europa pelo personalismo de Sgreccia e, nos EUA, o que mais se aproxima desta visão é a do paradigma das virtudes de Edmond Pellegrino $(2 ; 4 ; 5 ; 6 ; 7)$.

\section{Bioética Laica Secular ou bioética da qualidade de vida}

Non enim vivere bonum est, sed bene vivere (não é um bem viver, mas o viver bem)

Sêneca

Para Francesco D `Agostino, a bioética é ética, um ramo da filosofia e não da teologia moral. Portanto, nela devem ser empregados 


\section{Revista Brasileira de Bioética}

argumentos meramente racionais, controversos entre si, mais ou menos condivididos, mas nunca dogmáticos. Para ele, assim como para outros autores, a bioética é laica (mesmo a personalista), é antidogmática e antimetafísica (6). Bobbio dá um senso de exclusão de doutrina religiosa à palavra laico. O estado laico não confessional não é nem religioso e nem ateu; nem cristão e nem não cristão. Não representa uma nova cultura, mas uma condição de sobrevivência para todas as culturas (8). Da mesma forma para Umberto Eco, em seu debate com o Cardeal Carlo Maria Martini sobre o que crêem os que não crêem, a bioética laica não está vinculada a nenhum magistério que não seja aquele da reta razão. Neste sentido, ser laico não significa ser ateu ou agnóstico, mas apenas excluir as premissas metafísicas e religiosas que pretendam valer para toda a sociedade. A experiência moral, então, seria uma construção humana, sem uma fonte externa de valores (8).

Existem diversas correntes que fazem da bioética laica um conjunto de teorias morais diversas e não uma única visão dominante: utilitarismo, contratualismo, principialismo, liberalismo etc. Entretanto, como afirma Fornero, em muitos aspectos, suas argumentações se aproximam e partem do princípio da autonomia como o mais importante, da disponibilidade da vida humana (auto-disponibilidade), do conhecimento como instrumento de progresso, da não aceitação do sofrimento e a defesa do valor qualitativo da vida humana. Apresentam um conceito funcional de pessoa, sendo este o aspecto mais original e controverso da bioética laica. Enquanto para a bioética personalista ser pessoa depende da existência da natureza humana (substrato ontológico essencial existente em todos os seres humanos), para a bioética laica ser pessoa (e, portanto, sujeito ético e jurídico) depende da existência de determinadas características e funções tais como: consciência, capacidade de interação com outros seres e capacidade de auto-determinação. Assim, fetos, pacientes terminais, inconscientes ou com graves problemas neurológicos, estariam fora do sacrário secular da maior parte das abordagens da bioética laica (7).

Esta opção pluralista e liberal é o reconhecimento das diferenças como condição preliminar e normativa ao discurso bioético laico. Seu raciocínio é independente da religião e crença em Deus. Mas, aqui a Bioética Católica Personalista também está de acordo, pois utiliza argumentações filosóficas e não teológicas em seu discurso. 


\section{Dicotomia no discurso e na prática?}

O ex-presidente dos EUA, Ronald Reagan declarou:

“...legisladores, médicos e cidadãos devem reconhecer que o grande problema está em afirmar e tutelar a sacralidade da vida humana ou abraçar, por outro lado, uma ética social onde alguns tipos de vida devem ser mais protegidos, enquanto outros não. Como nação, nós devemos escolher entre a ética da sacralidade da vida e a ética da qualidade de vida".

Aquele país atualmente convive com este dilema em suas decisões políticas nos diversos âmbitos (7). Ambas as visões dominantes - a da sacralidade da vida e a da qualidade de vida - exprimem a complexa realidade da bioética atual. Este conflito dualista é mais intenso, e em muitos aspectos inconciliável em suas visões, quando se discutem problemas como o aborto, a eutanásia, as novas tecnologias reprodutivas e as pesquisas com células tronco-embrionárias. Nestes temas, a antítese entre as duas bioéticas - a metafísica e a relativista - é notória. Apesar disto, ambas estão constritas a co-existirem e dialogarem no contexto da sociedade pós-moderna.

Neste espírito, pode-se conceber a bioética sem a fundamentação teológica ou até que a bioética, verdadeiramente, seja laica em suas raízes fundamentais, como filha da ética filosófica e da reta razão. Mas, todas aquelas correntes que anulem a visão do homem como centro da fundamentação e da preocupação bioética, que forem contrárias à responsabilidade do homem para com o homem (sobretudo para com aqueles mais vulneráveis) e para com o ambiente em que vivemos (compromisso para com a continuidade da espécie), estarão e deverão estar condenadas a viverem isoladas no academicismo, formalmente fora do universo prático. A linha comum entre as bioéticas deve ser pautada no respeito à alteridade(9). 


\section{Revista Brasileira de Bioética}

\section{Referências}

1. Ferrer JJ \& Álvarez JC. Para fundamentar a bioética: teorias e paradigmas teóricos na bioética contemporânea. São Paulo, Edições Loyola, 2003.

2. Urban CA. Bioética clínica. Rio de Janeiro, Editora Revinter, 2003.

3. Potter VR. Bioethics: bridge to the future. New Jersey, Prentice-Hall, 1971.

4. Sgreccia E. Manuale di bioetica. Milão, Vita e Pensiero, 1999.

5. Pellegrino ED \& Faden AI. Jewish and catholic bioethics: an ecumenical dialogue. Washington, Georgetown University Press, 1999.

6. D`Agostino F. Diritto e giustizia. Milão, Edizioni San Paolo, 2000.

7. Fornero G. Bioetica cattolica e bioetica laica. Milão, Bruno Mondadori, 2005.

8. Eco U \& Martini CM. Em que crêem os que não crêem? Rio de Janeiro, Editora Record, 1999.

9. Forte B. L`Uno per I 'altro: per un `etica della trascendenza. Brescia, Editrice Morcelliana, 2003.

Recebido em: 3/2/2007 Aprovado em: 30/3/2007 